\title{
A REVIEW OF IMPROVEMENTS TO THE LIQUID COLLECTION SYSTEM USED IN THE PYROLYSIS PROCESS FOR PRODUCING LIQUID SMOKE
}

\author{
Nasruddin A. Abdullah ${ }^{1}$, Nandy Putra ${ }^{1 *}$, Imansyah Ibnu Hakim ${ }^{1}$, Raldi A.Koestoer ${ }^{1}$ \\ ${ }^{1}$ Heat Transfer Laboratory, Department of Mechanical Engineering, Faculty of Engineering, \\ Universitas Indonesia, Kampus UI Depok, Depok 16424, Indonesia
}

(Received: January 2017 / Revised: May 2017 / Accepted: November 2017)

\begin{abstract}
Liquid smoke can be produced by using the pyrolysis process. Biomass, as the raw material, is heated in a pyrolysis reactor to generate pyrolysis vapor. The pyrolysis vapors coming from the reactor are condensed in a liquid collection system to produce liquid smoke. A liquid collection system is a device used to convert smoke into liquid. Liquid smoke is often also called bio-oil, which is widely used as a fuel, as a preservative, and as other chemical substances. The objective of this paper was to provide the latest information on improving the liquid collection system from existing papers, and conclude with some inputs and application strategies. Studies were performed using the product parameters, equipment, and operational conditions referred to in the existing journal articles. Using a proper liquid collection system will give a better result in the liquid collection process.
\end{abstract}

Keywords: Biomass; Bio-oil; Liquid collection system; Liquid smoke; Pyrolysis

\section{INTRODUCTION}

Turning biomass into a useful product is a positive thing that can increase productivity and the economic level of society. The biomass used to produce liquid smoke comes from waste or from many production processes. This biomass, as a raw material, consists of cellulose, hemicellulose, lignin, and smaller amounts of other organic compounds(Bridgwater, 1999). There is an abundance of biomass resources throughout the world; in general, most biomass is obtained from palm oil, palm, corn, rice, and sugarcane, though slightly smaller amounts are obtained from other sources.

Liquid smoke is a liquid produced from the decomposition process of biomass. It can be acquiredby extracting it from biomass usingthe pyrolysis process, which is also known as pyrolysis liquid (Bridgwater, 2012; Sharma et al., 2015). In the fast pyrolysis process, a thermal decomposition of biomass occurs without the involvement of oxygen inside the process (Bridgwater, 2012); this process occurs at a middle range temperature and with high rate flows on biomass particles, and the vapor leaves the reaction zone shortly after it is produced (Czernik\&Bridgwater, 2004). In the fast pyrolysis process, biomass is decomposed to rapidly produce pyrolysis vapor, aerosol, carbon, and non-condensable gas. Throughthe condensation process,using aliquid collection system (LCS), a dark brown liquid is be produced; the heating value of this liquid is almost a half that of conventional oil (Bridgwater \& Peacocke, 2000).

Liquid smoke is known by many other terms: wood vinegar, bio-oil, pyrolysis liquid, pyrolysis oil, bio-crude oil, biofuel oil, pyroligneous tar, pyroligneous acid, wood liquid, and wood oil. At

\footnotetext{
${ }^{*}$ Corresponding author's email: nandyputra@eng.ui.ac.id, Tel: + 62-21-7270032, Fax: +62-21-7270033

Permalink/DOI: https://doi.org/10.14716/ijtech.v8i7.745
} 
the present, liquid smoke is already widely used in the food industry. Liquid smoke can be used as a flavoring, has a specific scent, is antimicrobial, and is an antioxidant thus suitable for preservative. Liquid smoke has been used commerciallyas an antibacterial (Suñenet al., 2001; Milly et al., 2005). Liquid smoke has the ability to preserve food as a result of its antimicrobial compounds and antioxidants, such as aldehydes, carboxylic acids, and phenols (Leroi \& Joffraud, 2000; Rørvik, 2000).

One of the most important components in producing liquid smoke is the LCS.In this component, the vapor generated by the reactor is cooled and liquefied;whether the cooling is rapid or slow depends on the type of LCS. Condensingthe vapor in an LCS is a difficult part of the operational process of fast pyrolysis because the pyrolysis vapor contain more aerosolsthan the condensable vapor (Bridgwater \& Peacocke, 2000). The cooling system process could be improved by using a vapor chamber (Hasnanet al., 2017).

Figure 1 shows the production schematic of liquid smoke. Starting with the raw-material preparation, next comes a reactor for generating pyrolysis vapor, then a cyclone to separate the solid particles from the vapor, and finally the pyrolysis vapor is liquefied, for which the a part of the equipment is the LCS. The products of this process are liquid smoke, non-condensable gas, and charcoal.

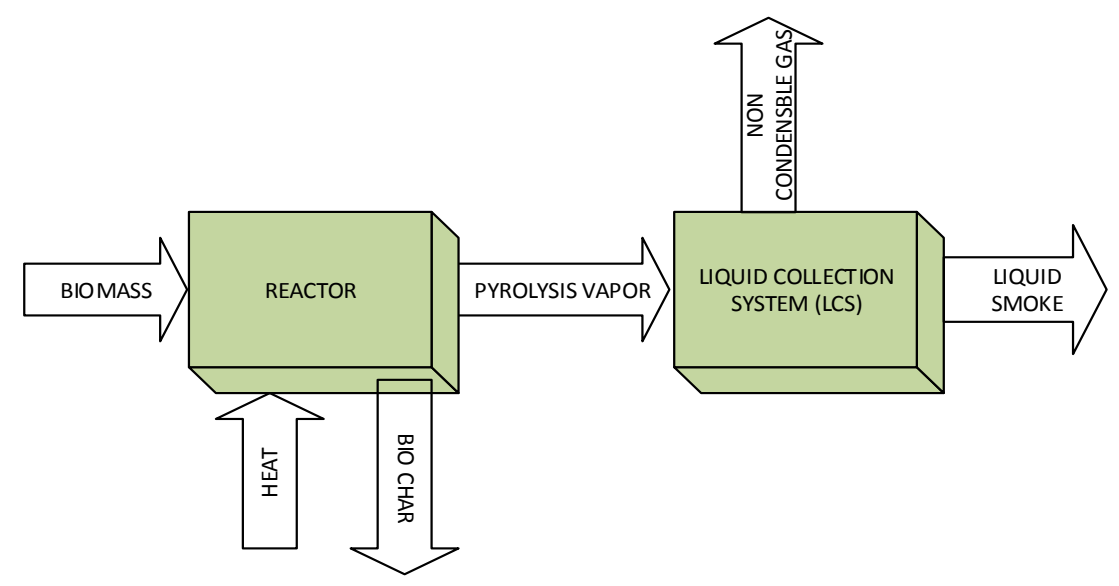

Figure 1 Production schematic of liquid smoke

Although, in fact, many researchers have focused on the pyrolysis reactor (Blasi, 2000; Babu \& Chaurasia, 2004), the cyclone separator, or even electrostatic precipitators (ESPs) used in pyrolysis technology (Luoet al., 2015), the LCS is the main component in producing liquid smoke.Therefore, this paper will summarize the potential improvementsin the LCS for producing liquid smoke. It is necessary to provide an overview of the improvements and research opportunities that can be performed, and this paper will provide information about the suggested development of LCSs, both from experiments and simulations. The LCS requires rapid cooling to minimize the second reaction and for it to be able to condense the pyrolysis vapor. The product that is condensed in the LCS has a very low partial pressure; this condition is crucial to the LCS process design (Bridgwater, 2012). The objective of this paper is to provide the latest information on improvements in the LCS, and conclude with some inputs and application strategies.

Several types of heat exchanger are commonly applied in LCS, including a tubular heat exchanger, cyclone condenser, spray column, double surface condenser, scrubber, and several another types. The components that enter the LCS can be classified into three categories based on their physical condition. These are non-condensable gases, vapor, aerosols, and a little charcoal that is not trapped in the cyclone. The non-condensable gases consist of hydrogen, 
carbon monoxide, carbon dioxide, and other light hydrocarbons produced by the reaction of the pyrolysis process; the amount of non-condensable gases ranges from 10-20 wt $\%$ of pyrolysis products (Mohanet al., 2006).

The condenser design for the fraction of each compound in the pyrolysis process is based on the operational temperature of the heat exchanger. The boiling point, density, vapor pressure, and molecular weight of some liquid smoke compounds will affect the condensation processes in the LCS. The vapor produced in the reactor contains many compounds from the cooling process, such as water and organic substances; these substances can be condensed. There are also some other organic compounds produced, consisting of carboxylic acids, alcohol, esters, and phenols, all of which have the different boiling point. The vapor that is generated by the reactor is cooled and liquefied in the LCS, which provides rapid cooling or slow cooling depending on the type of LCS. How best to condense the relative amount of vapor and aerosol is very difficult to ascertain, due to each substance being partially transformed into other forms, depending on the environmental conditions of the temperature and constituents. Some reports state that $90 \%$ vapor flows out of the pyrolysis reactor in the aerosol form it is highly dependent on raw materials and the reaction conditions (Daugaard, 2003).

The Liquid in LCS will be collected base on different properties of pyrolysis vapor fractionally, based on the saturation temperature of each substance. Each fraction of the compound in the vapor stream will condense when the temperature of vapor drops below the fraction's boiling point or saturation temperature. Saturation temperature $T_{\text {sat }}$ can be calculated from the vapor pressure $\mathrm{Pv}$ of each compound from the vapor stream using the Clausius-Clapeyronequation:

$$
\ln \left(\frac{P_{v}}{P_{o}}\right)=\frac{\Delta H_{v a p}}{R}\left(\frac{1}{T_{o}}-\frac{1}{T_{s a t}}\right)
$$

The following equation is used to obtain vapor pressure:

$$
P_{v}=\frac{m_{f} C_{o i l} R_{u} T_{0}}{M W}
$$

where $P o$ is the saturation pressure at standard temperature; $T_{o}$ and $(\Delta H)_{v a p}$ arethe vapor temperature and enthalpy from the compound, respectively; $R_{u}$ is universal gas constant; $T_{0}$ is the standard temperature at volumetric flows; and $M W$ is the molecular weight.

\section{METHODOLGY}

The LCS is a challenge for the researcher when it comes to producing liquid smoke; the literature discusses several different options on the kindsof LCS that may be used. In general, LCSs can be classified into three main categories, which area spraytower orcolumn, heat exchanger, and a combination of both. Furthermore, ESPs are also used to capture the aerosolsoutside ofthe condensation system, whether using a spray column, heat exchanger, or the combination of both. The raw materials are influential in determining the type of LCS that is needed. Some reportsexplain that $90 \%$ of the vapor that flows out from the pyrolysis reactor is in aerosol form. This is highly dependent on the raw material and the reaction condition in the pyrolysis reactor. Studies have been performed using the product parameters, equipment, and operational conditions referred to in the existing paper. Using an appropriate LCS will result in a liquefaction process that is more effective and efficient. 


\section{LIQUID COLLECTION SYSTEM (LCS)}

\subsection{LCS with Spray Quench and DistillationColumn}

Large-scale systems usually use a spray-quench column for condensation. The liquid smoke produced is cooled prior to entering the chiller, then it is circulated in the quenching column by using a pump, and is sprayed to a hot vapor in the column. This process will transfer heat from the hot fluid to the cold fluid directly, and will condense the vapors when the saturation temperatures are reached. The weakness of this system is that it is very difficult to fractionate the product because it is very difficult to control the temperature of the cooling.

Some studies have been conducted relating to LCSs, including the spray tower or column type. For example, a two-level, jacketed, countercurrent spray column, which has a diameter of 0.07 $\mathrm{m}$ and a height of $1.68 \mathrm{~m}$. An Ordina shell 941 was used to spray the liquid oil at start-up to control the condensing temperature at $1{ }^{\circ} \mathrm{C}$, in (Westerhof et al., 2007) study. The first-stage condenser is known as the prime condenser, which operates at a temperature $20^{\circ} \mathrm{C}$, and the second condenser maintains a temperature of $0^{\circ} \mathrm{C}$, and is intended to condense any residual vapor that was not condensed in the first condenser. By applying this method it is possible to control the moisture content of the product in a wayother than controlling the water content in the raw materials, which will be decomposed in the reactor.

Lindfors at el. (2014) used a sieve-plate column (scrubber) on the pyrolysis vapor to condense it in the first stage of liquid recovery. To condense the vapor generated by the reactor in the first stage, direct and indirect cooling were applied to the liquid from the hot vapor; inlet direct cooling was applied in the sieve-plate column, then the thermal degradation reaction of the collected pyrolysis liquids was reduced (Lindfors et al., 2014). A hydrocarbon liquid was used as the liquid cooler in the scrubber. To adjust the outlet gas temperature, indirect cooling was applied by varying the cooling temperatures.

Fractional distillation is another type of LCS. The $47.5 \mathrm{~mm}$ ID fractional distillation column comprises fourstages and has a total length of $430 \mathrm{~mm}$. Each stage was packed with $140.0 \mathrm{~g}$ of 5 mm glass ballotini in (Yinet al., 2013) study. The pyrolysis vapors were condensed in the different stages in the fractional distillation column. Furthermore, the four stages of heat exchange and one stage of ESP were installed to separate the liquid smoke. Each stage of the condenser was maintained at average temperatures of $310 \mathrm{~K}, 298 \mathrm{~K}, 296.5 \mathrm{~K}$, and $297 \mathrm{~K}$, respectively. Resident time of each condenser was around 2.4 seconds. The remaining vapor was captured by using ESP.

To reduce the water content in the bio-oil, two stages of cyclone condenser were installed complete with a stage of ESP in (Gootyet al., 2014) study. The first condenser was maintained at a temperature of $80^{\circ} \mathrm{C}$ in order to condense the heavy fraction of the liquid smoke. The vapor coming out from the first-stage condenser flowed into the ESP to absorb its aerosol. In the second condenser, the temperature was maintained at $10^{\circ} \mathrm{C}$ to condense all of the moisture content and the light fraction of vapor; the same method was also employed to minimize the water content in the product up to $1 \mathrm{wt} \%$, and get better efficiency.

\subsection{LCS with Heat-exchanger-type Cooling}

Heat exchangers in LCSs can cause slow cooling and can condense the components produced from lignin, but this process tends to cause a blockage in the heat exchanger due to the high viscosity of the liquid components produced from lignin (Bridgwateret al., 1999). It is easier to use a heat exchanger to control the temperature, so this is easier to implement in the condensation process that aims to fractionate the products based on the boiling point of each liquid-smoke product.

Some previous research has been done on LCSs that use heat exchangers in the cooling process. In (Lédéet al., 2007) research, a heat exchanger was installed in series. They used water as a 
cooling fluid, and the diameter of the heat exchanger was $0.01 \mathrm{~m}$ and its length was $0.5 \mathrm{~m}$. The heavy fraction of the liquid smoke was condensed by using air, and a refrigerated coil with temperature $258 \mathrm{~K}$ was mounted at the end of the system was to condense the light fractions of the liquid smoke.

The heat exchanger used can be followed by two stages of ESP and two stages of another heat exchanger to condense the pyrolysis vapor (Predel \& Kaminsky, 1998). A three-stage of heat exchanger can also be used, which is equipped with two stages of ESP and a glass-wool filter to capture the residual aerosols. The temperature of the heat exchanger is adjusted to the boiling point for each fractionation (Pollardet al., 2012). The total decrease in temperature that occurs in all four tubes is $278^{\circ} \mathrm{C}$ and cooling rate is $60^{\circ} \mathrm{C} / \mathrm{sec}$ (Boatenget al., 2007).

In (Miaoet al., 2004) study, hot water was circulated in the first-stage condenser to reduce the vapor temperature and condense the pyrolysis vapor at the boiling point, while the second stage used ice to condense the remaining pyrolysis vapor. A single stage of the condenser was used by (Yuliansyahet al., 2015)to liquefy the vapor with low-density polyethylene (LDPE) used as the raw material.

Three condensers (of $10 \mathrm{~cm}$ diameter $\times 200 \mathrm{~cm}$ length) were used in series along with a coolanttemperature controller with a water jacket in Kimet al.'s (2016) study. Hot water at $85-90^{\circ} \mathrm{C}$ was circulated at the first condenser. Water was used as the coolant liquid in the second condenser with the temperature maintained at $45-50^{\circ} \mathrm{C}$, the temperature was maintained at $10-15^{\circ} \mathrm{C}$ in the third condenser. The outgoing vapor temperaturesin each condenser are $121^{\circ} \mathrm{C}, 107^{\circ} \mathrm{C}$, and $25^{\circ} \mathrm{C}$ for the first, second, and third condensers, respectively. A multi-stage condenser needs a sweeping gas to flow the vapor through the condenser; in the multi-stage condenser, the bio-oil fractionation temperature, bio-oil composition, water content, viscosity, and density are influenced by the flow rate of the sweeping gas. The temperature increase will influence the composition and water content of the bio-oil in the third condenser. Two glass-trap condensers in the LCS were filled cooling fluidin (Yang \& Ani, 2016) researchto liquefy the vapor generated by a microwave reactor.

Two stages and three stages of condensinghave been applied to dilute the condensable pyrolysis vapor in (Schulzkeet al., 2016) study. The experiment with two-stage condenser was conducted, and used a vapor temperature of $539^{\circ} \mathrm{C}$. The temperature was kept at $90^{\circ} \mathrm{C}$ in the first-stage cooler and ESP. The vapor temperature leaving the first stage was $89^{\circ} \mathrm{C}$. In the second stage, the cooling temperature was maintained at $2^{\circ} \mathrm{C}$ with water used as the cooling fluid. The three-stage condenser was installed with a different cooling temperature for each condenser; these temperatures were $120^{\circ} \mathrm{C}, 90^{\circ} \mathrm{C}$, and $2^{\circ} \mathrm{C}$, and the temperature of the vapor that entered the first condenser was $550^{\circ} \mathrm{C}$. The temperature of the vapors leaving the first and second condensers were $115^{\circ} \mathrm{C}$ and $87^{\circ} \mathrm{C}$, respectively. The higher boiling fraction shows a high heat value, and was low in water and acid. Water and some kind of acid will be obtained from low-temperature cooling.

An impinge type of condenser train system was used to collect liquid from pyrolysis vapor in (Kuo et al., 2017) study.This consisted of four condenser tubes, each with a size of $10 \times 20 \mathrm{~cm}$, installed in series. The tube was cooled using ice, and, at the end,the pyrolysis vapors were condensed at two different temperatures outside distillation column after leaving the fractional distillation column. At the bottom of the distillation column, bio-oil was collected at $136^{\circ} \mathrm{C}$, and is regarded as a heavier oil. Meanwhile, bio-oils were collected at $20^{\circ} \mathrm{C}$ and $0^{\circ} \mathrm{C}$ as lighter oils. And the remaining of non-condensable gases were vent to the atmosphere.

(Mazlanet al., 2015) used a cooled ethylene-glycol bath to provide the cooling fluid, which was immersed into two condensers to liquefy the vapor at below $-10^{\circ} \mathrm{C}$ to improve condensation efficiency.(Jinet al., 2015) used a series of four ice-bath condensers immersed in ice water to 
condense the pyrolysis vapor.

An LCS consisting of three condensers connected in series (condenser 1, C-ESP, and condenser 3) was used in (Liet al., 2015) research. The water was condensed primarily in condenser 3, a higher temperature was maintained to collect the heavy components in condenser 1 at $80^{\circ} \mathrm{C}$, and the temperature in C-ESP was controlled at $70^{\circ} \mathrm{C}$. To recover the water and light components from the vapor, condenser 3 was immersed in an ice-water bath.

An ice-water-cooled impinge type of LCS was combined with a countercurrent, double-pipe condenser in (Luoet al., 2017) experiment, in which the vapors from the reactor entered the icewater-cooled impinge and went into the condenser at the bottom. The cooling fluid used was propylene glycol/water, of $50 / 50 \mathrm{vol} \%$, with an inlet temperature of $-10^{\circ} \mathrm{C}$. At this stage, the light fraction of the bio-oil was collected.

In (Messinaet al., 2017) study, volatile products were condensed and collected using a seriesof three condensers at $-10^{\circ} \mathrm{C}$, which was immersed in the thermostatic bath.

\subsection{Combination of LCS Spray Column and Heat Exchanger}

To determine the advantages of each type of LCS, a merger of these two processes was applied. A spray column is able to condense vapors in larger quantities, while it is easier to control the temperature in a heat exchanger, so it is easier to complete fractional condensation of the vapor. (Westerhofet al., 2007) employed two condensers that were built with several nozzles and coupled to a heat exchanger inside. A pump was used to circulate a coolant into the condenser for direct cooling of the pyrolysis vapor through the condenser. Figure 2 shows the combined LCS process comprising a heat exchanger and two quench columns. The pyrolysis vapors entered the column and were sprayed with a coolant before being cooled in a heat exchanger. The same process occurred in the next column. The type of condenser was a cyclonic condenser.

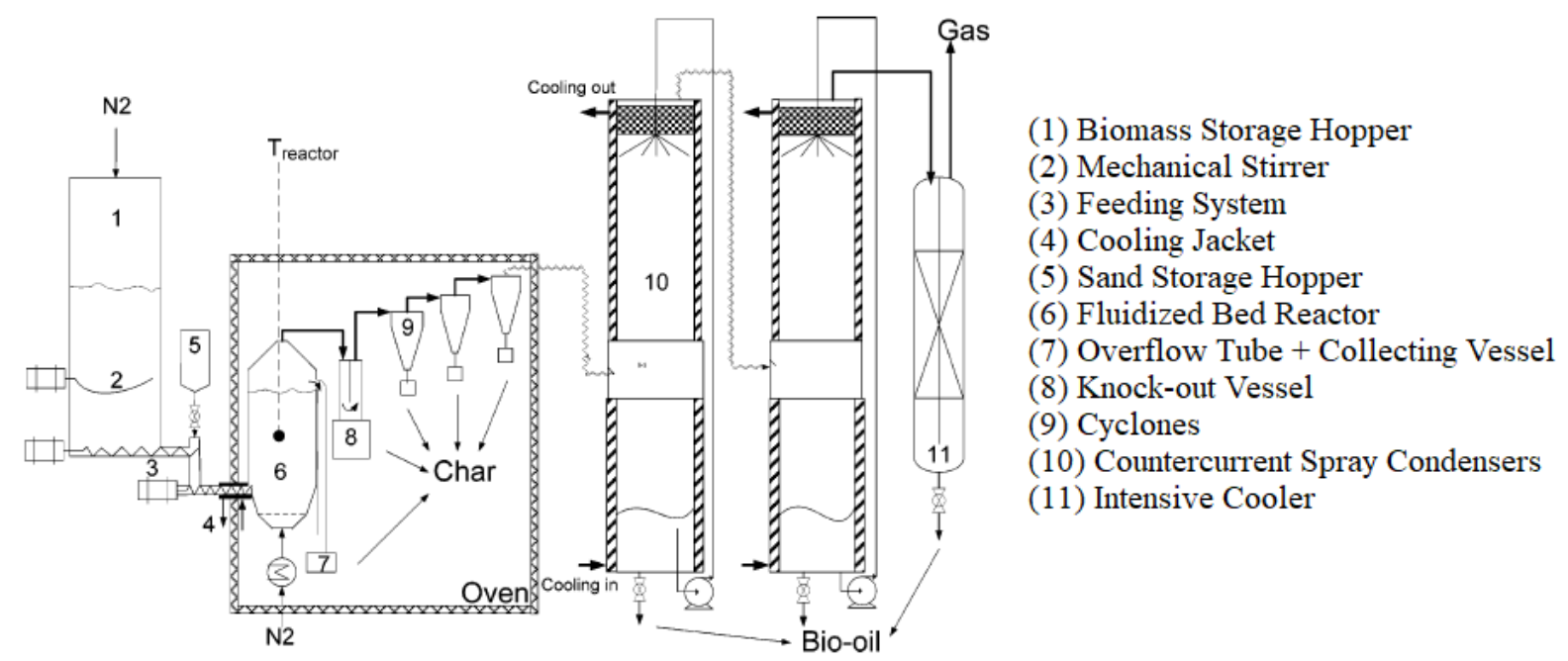

Figure 2 Combined LCS process with two quench columns (Westerhofet al., 2007)

The use of multiple sprayers combined with heat exchangers can accelerate the liquefaction process and rapidly change the pyrolysis vapor. The amount of heat is more easily absorbed in an LCS when these two processes are combined (Zhenget al., 2008). A pipe-bundle quencher was used by (Luoet al., 2004)to condense the pyrolysis vapor produced by the reactor, andwater was used as cooling fluid.To obtain the fractions of bio-oil in accordance with the conditions of the boiling points of each component, (Schulzkeet al., 2016) used a four-stage condenser. Each condenser was maintained at a certain temperature, these temperatures being $300^{\circ} \mathrm{C}, 100^{\circ} \mathrm{C}, 0^{\circ} \mathrm{C}$, and $-20^{\circ} \mathrm{C}$, respectively. Nearly $90 \%$ of the lighter components were condensed in the condenser, 
which was maintained at $0^{\circ} \mathrm{C}$.

Two quencher columns equipped with condensers connected in series were installed to quench condensable and non-condensable gas in (Wuet al., 2016) study. A spraying column and a heatexchanger cooler (shell-tubetype) were employed for each condenser and a chilling machine with a coolant temperature of $288 \mathrm{~K}$ was equipped for each shell and tube cooler to control the process temperature in the condenser. In the first condenser, the bio-oil temperature was $313-323 \mathrm{~K}$ and it was $293 \mathrm{~K}$ in the second condenser. ESP was used to capture the aerosols from the condenser; the yield of the product depended on the raw materials that were used. In the series of condensers, bio-oils were collected of almost $88 \mathrm{wt} \%, 9.8 \mathrm{wt} \%, 1.9 \mathrm{wt} \%$, respectively for the Douglas-fir sawdust.

Table 1The summary of LCS type and classification

\begin{tabular}{|c|c|c|c|}
\hline LCS Classification & Researcher & Year & Type of LCS \\
\hline \multirow{4}{*}{$\begin{array}{l}\text { LCS with spray- } \\
\text { quench column and } \\
\text { distillation column }\end{array}$} & Westerhof et al. & 2007 & $\begin{array}{l}\text { Two-level, jacketed, countercurrent spray } \\
\text { column }\end{array}$ \\
\hline & Lindfors & 2014 & Sieve-plate column (Scrubber) \\
\hline & Yin et al. & 2013 & Fractional distillation column \\
\hline & Gooty et al. & 2014 & $\begin{array}{l}\text { Two stages of cyclone condenser and a stage of } \\
\text { ESP }\end{array}$ \\
\hline \multirow{14}{*}{$\begin{array}{l}\text { LCS with heat- } \\
\text { exchanger-type } \\
\text { cooling }\end{array}$} & Predel and Kaminsky & 1998 & $\begin{array}{l}\text { Two stages of heat exchanger followed by two } \\
\text { stages of ESP }\end{array}$ \\
\hline & Miao et al. & 2004 & $\begin{array}{l}\text { One stage of condenser with hot water and two } \\
\text { stages of condenser with ice water }\end{array}$ \\
\hline & Yuliansyah et al. & 2015 & Vertical and one stage condenser \\
\hline & Lédé et al. & 2007 & Series of two heat exchangers \\
\hline & Pollard et al. & 2012 & $\begin{array}{l}\text { Three stages of heat exchanger followed by two } \\
\text { stages of ESP }\end{array}$ \\
\hline & Mazlan et al. & 2015 & $\begin{array}{l}\text { Two condensers immersed into a cooled } \\
\text { ethylene-glycol bath }\end{array}$ \\
\hline & Jin et al. & 2015 & Four condensers immersed into an ice bath \\
\hline & Li et al. & 2015 & Two condensers in series and one ESP \\
\hline & Kim et al. & 2016 & Three condensers in series \\
\hline & Schulzke et al. & 2016 & $\begin{array}{l}\text { Two stages and followed by three stages of } \\
\text { condensers }\end{array}$ \\
\hline & Yang and Ani & 2016 & Glass-trap condenser \\
\hline & Kuo et al. & 2017 & $\begin{array}{l}\text { Four stages of an impinge type of condenser } \\
\text { train }\end{array}$ \\
\hline & Luo et al. & 2017 & $\begin{array}{l}\text { One countercurrent, double-pipe impinge-type } \\
\text { LCS cooled in ice water }\end{array}$ \\
\hline & Messina et al. & 2017 & $\begin{array}{l}\text { Three condensers immersed into a thermostatic } \\
\text { bath }\end{array}$ \\
\hline \multirow{5}{*}{$\begin{array}{l}\text { Combination of an } \\
\text { LCS spray column } \\
\text { and heat exchanger }\end{array}$} & Luo et al. & 2004 & One pipe-bundle quencher \\
\hline & Westerhof et al. & 2007 & $\begin{array}{l}\text { Two quenching columns combined with a } \\
\text { cyclonic condenser }\end{array}$ \\
\hline & Schulzke et al. & 2016 & Four stages of condenser \\
\hline & Wu et al. & 2016 & $\begin{array}{l}\text { Two quencher spraying columns equipped with } \\
\text { condensers in series and an ESP }\end{array}$ \\
\hline & Huang et al. & 2016 & $\begin{array}{l}\text { One distillation column and two water } \\
\text { condensers }\end{array}$ \\
\hline
\end{tabular}

Huang et al. (2016) used an LCS equipped with a distillation column and two water condensers. 
The bio-oils were condensed at $120^{\circ} \mathrm{C}$ and $80^{\circ} \mathrm{C}$ in the column, and at $0^{\circ} \mathrm{C}$ for water condenser; the bio-oils collected in the column are heavy fractions and those collected in the water condenser are the light fractions.

A summary of types of LCS improvements are shown in Table 1.

\section{CONCLUSION}

The improvement of LCSs has become a serious concern of researchers with respect to the vapor condensation process. A spray tower or column has been used in LCSs to condense large quantities of liquid smoke without fractionation processes. Heat exchangers are widely applied in the condensation processes for liquid smoke due to the ease of controlling the cooling temperature. A heat exchanger is more suitable for using as the LCS to separate the heavy fractions and light fractions in liquid smoke. Using a higher boiling fraction showed a high heating value, and a result low in water and acid, which are obtained at a low temperature of cooling fluid. From the assessment of LCSs it can be concluded that there are improvements that can be made, such as the use of heat exchangers to produce liquid smoke for each fraction according to their boiling point. The current trends in LCS research for pyrolysis suggest fractional condensation can be used to obtain the required products. A suitable design is needed for the heat exchanger as a result of the thermal properties of the vapor. Research on liquid smoke based on thermofluids still needs to be conducted. There is a lack of data on thermal properties, especially for local materials from Indonesia, which provides opportunities for researchers from Indonesia to study LCSs more, especially those based on thermofluids.

\section{REFERENCES}

Babu, B.V., Chaurasia, A.S., 2004. Pyrolysis of Biomass: Improved Models for Simultaneous Kinetics and Transport of Heat, Mass and Momentum. Energy Conversion and Management, Volume 45(9-10), pp. 1297-1327

Blasi, C.D., 2000. Modelling the Fast Pyrolysis of Cellulosic Particles in Fluid-bed Reactors. Chemical Engineering Science, Volume 55(24), pp.5999-6013

Boateng, A.A., Daugaard, D.E., Goldberg, N.M., Hicks, K.B., 2007. Bench-scale Fluidized-bed Pyrolysis of Switchgrass for Bio-oil Production. Industrial \& Engineering Chemistry Research, Volume 46(7), pp.1891-1897

Bridgwater, A.V, 1999. Principles and Practice of Biomass Fast Pyrolysis Processes for Liquids. Journal of Analytical and Applied Pyrolysis, Volume 51(1), pp.3-22

Bridgwater, A.V., 2012. Review of Fast Pyrolysis of Biomass and Product Upgrading. Biomass and Bioenergy, Volume 38, pp.68-94

Bridgwater, A.V., Meier, D., Radlein, D., 1999. An Overview of Fast Pyrolysis of Biomass. Organic Geochemistry, Volume 30(12), pp. 1479-1493

Bridgwater, A.V., Peacocke, G.V.C., 2000. Fast Pyrolysis Processes for Biomass. Renewable and Sustainable Energy Reviews, Volume 4(1), pp. 1-73

Czernik, S., Bridgwater,A.V., 2004. Overview of Applications of Biomass Fast Pyrolysis Oil. Energy \& Fuels, Volume 18(2), pp. 590-598

Daugaard, D.E., 2003. The Transport Phase of Pyrolytic Oil Exiting a Fast Fluidized Bed Reactor. Docotoral of Philosophy Dissertation. Iowa State University, http://lib.dr.iastate.edu/rtd/1431

Gooty,A.T., Li, D., Berruti, F., Briens, C., 2014. Kraft-lignin Pyrolysis and Fractional Condensation of its Bio-oil Vapors. Journal of Analytical and Applied Pyrolysis, Volume 106, pp.33-40 
Hasnan, A., Putra, N., Septiadi, W.N., Ariantara, B., Abdullah, N.A., 2017. Vapor Chamber Utilization for Rapid Cooling in the Conventional Plastic Injection Molding Process. International Journal of Technology, Volume 8(4), pp.690-697

Huang, A.-N., Hsu, C.-P., Hou, B.-R., Kuo, H.-P., 2016. Production and Separation of Rice Husk Pyrolysis Bio-oils from a Fractional Distillation Column Connected Fluidized Bed Reactor. Powder Technology, Volume 323, pp. 588-593

Jin, W., Singh, K., Zondlo, J., 2015. Co-processing of PyrolysisVapors with Bio-chars for Exsitu Upgrading. Renewable Energy, Volume 83, pp.638-645

Kim, P., Weaver, S., Labbé, N.,2016. Effect of sweeping gas flow rates on temperature-controlled multistage condensation of pyrolysis vapors in an auger intermediate pyrolysis system. Journal of Analytical and Applied Pyrolysis, 118, pp. 325-334.

Kuo, H.-P., Hou, B.-R., Huang, A.-N., 2017. The Influences of the Gas Fluidization Velocity on the Properties of Bio-oils from Fluidized Bed Pyrolyzer with In-line Distillation. Applied Energy, Volume 194, pp.279-286

Lédé, J., Broust, F., Ndiaye, F.-T., Ferrer, M., 2007. Properties of Bio-oils Produced by Biomass Fast Pyrolysis in a Cyclone Reactor. Fuel, Volume 86(12), pp.1800-1810

Leroi, F., Joffraud., J.J., 2000. Salt and Smoke Simultaneously Affect Chemical and Sensory Quality of Cold-smoked Salmon during $5^{\circ} \mathrm{C}$ Storage Predicted using Bactorial Design. Journal of Food Protection, Volume 63(9), pp. 1222-1227

Li, D., Briens, C., Berruti, F., 2015. Improved Lignin Pyrolysis for Phenolics Production in a Bubbling Bed Reactor-effect of Bed Materials. Bioresource Technology, Volume 189, pp.714

Lindfors, C.,Kuoppala,E., Oasmaa, A., Solantausta, Y., Arpiainen, V., 2014. Fractionation of Bio-oil. Energy \& Fuels, Volume 28, pp.5785-5791

Luo, G., Chandler, D.S., Anjos, L.C., Eng, R.J., Jia, P., Resende, F.L., 2017. Pyrolysis of Whole Wood Chips and Rods in a Novel Ablative Reactor. Fuel, Volume 194, pp. 229-238

Luo, K., Li, Y., Zheng, C., Gao, X., Fan, J., 2015. Numerical Simulation of Temperature Effect on Particles Behavior via Electrostatic Precipitators. Applied Thermal Engineering, Volume 88, pp. 127-139

Luo, Z., Wang, S., Liao, Y., Zhou, J., Gu, Y., Cen, K., 2004. Research on Biomass Fast Pyrolysis for Liquid Fuel. Biomass and Bioenergy, Volume 26(5), pp.455-462

Mazlan, M.A.F., Uemura, Y., Osman, N.B., Yusup, S., 2015. Fast Pyrolysis of Hardwood Residues using a Fixed Bed Drop-type Pyrolyzer. Energy Conversion and Management, Volume 98, pp.208-214

Messina, L.G., Bonelli, P., Cukierman, A., 2017. In-situ Catalytic Pyrolysis of Peanut Shells using Modified Natural Zeolite. Fuel Processing Technology, Volume 159, pp.160-167

Miao, X., Wu, Q., Yang, C., 2004. Fast Pyrolysis of Microalgae to Produce Renewable Fuels. Journal of Analytical and Applied Pyrolysis, Volume 71(2), pp.855-863

Milly, P.J.,Toledo, R.T., Ramakrishnan, S., 2005. Determination of Minimum Inhibitory Concentrations of Liquid Smoke Fractions. Journal of Food Science, Volume 70(1), pp. M12-M17

Mohan, D., Pittman, C.U., Steele, P.H., 2006. Pyrolysis of Wood/biomass for Bio-oil: ACritical Review. Energy \& Fuels, Volume 20(3), pp.848-889

Pollard, A.S., Rover, M.R., Brown, R.C., 2012. Characterization of Bio-oil Recovered as Stage Fractions with Unique Chemical and Physical Properties. Journal of Analytical and Applied Pyrolysis, Volume 93, pp.129-138

Predel, M., Kaminsky, W., 1998. Pyrolysis of Rape-seed in a Fluidised-bed Reactor. Bioresource Technology, Volume 66(2), pp.113-117

Rørvik, L.M., 2000. Listeria Monocytogenes in the Smoked Salmon Industry. International Journal of Food Microbiology, Volume 62(3), pp.183-190 
Schulzke, T., Conrad, S., Westermeyer, J., 2016. Fractionation of Flash Pyrolysis Condensates by Staged Condensation. Biomass and Bioenergy, Volume 95, pp.287-295

Sharma, A., Pareek, V., Zhang, D., 2015. Biomass Pyrolysis-A Review of Modelling, Process Parameters and Catalytic Studies. Renewable and Sustainable Energy Reviews, Volume 50, pp. 1081-1096

Suñen, E., Fernandez-Galian, B., Aristimuño, C., 2001. Antibacterial Activity of Smoke Wood Condensates Against Aeromonas Hydrophila, Yersinia Enterocolitica andListeria Monocytogenes at Low Temperature. Food Microbiology, Volume 18(4), pp.387-393

Westerhof, R.J., Kuipers, N.J., Kersten, S.R., van Swaaij, W.P., 2007. Controlling the Water Content of Biomass Fast Pyrolysis Oil. Industrial \& Engineering Chemistry Research, Volume 46(26), pp.9238-9247

Wu, S.-R., Chang, C.-C., Chang, Y.-H., Wan, H.-P., 2016. Comparison of Oil-tea Shell and Douglas-fir Sawdust for the Production of Bio-oils and Chars in a Fluidized-bed Fast Pyrolysis System. Fuel, Volume 175, pp.57-63

Yang, A.L.C., Ani, F.N., 2016. Controlled Microwave-induced Pyrolysis of Waste Rubber Tires. International Journal of Technology, Volume 7(2), pp.314-322

Yin, R., Liu, R., Mei, Y., Fei, W., Sun, X., 2013. Characterization of Bio-oil and Bio-char Obtained from Sweet Sorghum Bagasse Fast Pyrolysis with Fractional Condensers. Fuel, Volume 112, pp.96-104

Yuliansyah, A.T., Prasetya, A., Ramadhan, M.A.A., Laksono, R., 2015. Pyrolisis of Plastic Waste to Produce Pyrolytic Oil as an Alternative.International Journal of Technology, Volume 6(7), pp.1076-1083

Zheng, J.-1., Yi, W.-m., Wang, N.-n., 2008. Bio-oil Production from Cotton Stalk. Energy Conversion and Management, Volume 49(6), pp.1724-1730 